\title{
Exports, Foreign Direct Investment and Economic Growth: An Empirical Application for Nigeria
}

\author{
Sikiru Jimoh BABALOLA (Corresponding author) \\ Department of Economics, Modibbo Adama University of Technology \\ (Formerly Federal University of Technology) \\ PMB 2076, Yola, Adamawa State, Nigeria \\ E-mail: sjbabalola@yahoo.com \\ Shehu Dan Hassan DOGON-DAJI \\ Senior Lecturer, Department of Economics \\ Usmanu Danfodiyo University, PMB 2346, Sokoto, Sokoto State, Nigeria \\ E-mail: danhassandaji@yahoo.com \\ Jimoh Olakunle SAKA \\ Lecturer, Department of Economics \\ Lagos State University, Ojo, PMB 0001, Ojo, Lagos State, Nigeria \\ E-mail: jaystatistics@yahoo.com
}

Received: January 26, 2012

doi:10.5539/ijef.v4n4p95

\author{
Accepted: March 7, $2012 \quad$ Published: April 1, 2012 \\ URL: http://dx.doi.org/10.5539/ijef.v4n4p95
}

\begin{abstract}
The paper examines the relationship among exports, Foreign Direct Investment (FDI) and economic growth in Nigeria over the period 1960-2009. The time series properties of the variables are examined using the Phillips-Peron technique due to its robustness to a wide variety of serial correlation and heteroscedasticity. The results of Johansen cointegration test indicate existence of at least six cointegrating vectors. The error correction coefficient shows that deviation from long run RGDP path is corrected by about $48 \%$ over the following year. As a way of correcting for multicollinearity, we re-estimate the models of the static regression using a Fully Modified Least Squares Method (FMOLS) and error correction coefficient. We find out that the removal of Degree of openness (DOP) variable may be detrimental even though the percentage deviation from equilibrium does not seem to change. The paper therefore concludes by shedding more light on the relevance of the degree of openness and this can facilitate more FDI inflows capable of accelerating the growth process. The paper thus recommends immediate focus on more reforms/policies that will create enabling environment for FDI inflows and export growth thereby reducing the growth and development barriers in Nigeria.
\end{abstract}

Keywords: Exports, FDI, Economic growth, Cointegration and ECM

JEL Classification Codes: C32, F21, F43, O11, O16

\section{Introduction and Background}

The role of exports and FDI in promoting economic growth has much been recognized across the world. This has gradually established the importance of openness and of course disappearance of import substitution policy in the modern development economic literature and policy (Maneschiold, 2008). Exports have already been considered as the most important source of foreign exchange, that are required most by developing countries to ease their balance of payments problem and reduce unemployment through generation of job opportunities. Exports help the country to integrate in the world economy. Exports and FDI also allow domestic production to achieve a high level of economies of scale (Ullah, Uz-Zaman, Farooq, \& Javid, 2009; Abou-Stait, 2005; Musonda, 2007; Al-Yousif, 1999).

The experience of many developed, some emerging economies and more precisely the Asian Tigers such as Singapore, Hong Kong, Taiwan, South Korea and recently China has provided good example of the importance of 
the export sector to economic growth and development. This has not only made economists to stress the vital role of exports and FDI as the engine of economic growth but also engaged the attention of researchers and policy makers in that direction (Abou-Stait, 2005). Nevertheless, the Nigerian economy too was well known for its exports-driven growth particularly before the discovery of oil when the country used to record a huge success in the export of non-oil products especially agricultural produce. It is obvious that for long the non-oil exports in Nigeria had been taken over by the oil sector, even though the performance of the economy in the last decade was quite very surprising. This is partly because of the country's stronger ties with developed and emerging economies especially after the transition to civilian rule in 1999 and partly the recent global economic and of course Niger Delta crises, which rendered the oil sector at disadvantage when it comes to the sector's contribution to the growth of the economy. This underscores the need to not only diversify the economy but also target the country's rate of growth through agricultural and non-oil exports. This is also particularly important when one considers the comparative advantage the country has had in agricultural and non-oil exports as a labour abundant economy with huge minerals and arable but uncultivated lands.

Generally, the driving factors of surge in FDI inflows to developing countries and Nigeria in particular are basically abundance of natural resources, large market or favourable business environment, political and institutional reforms, among others. Structurally, the oil and extractive sectors of the economy dominate in attracting FDI into Nigeria.

Historical data on Nigerian economy indicate that between 1960 and 1970, total exports grew from $\$ 475.19$ million to $\$ 1.24$ billion while FDI also grew from almost zero to $\$ 1.40$ billion. The real GDP was also on the increase from $\$ 3.48$ billion to $\$ 4.41$ billion during the same period. The economy also witnessed increase in the three macroeconomic variables of interest during the period 1970-1980. By the year 2009, total exports stood at $\$ 59.04$ billion while FDI and RGDP stood at $\$ 2.95$ and $\$ 3.53$ billion respectively. It is worthy of note that between 2000-2009, naira highly depreciated against US dollar and this accounted for the lower values of the three variables when compared to what is obtainable in terms of Nigerian currency (naira).

Today, many empirical works support the export led economic growth hypothesis, even though there is no consensus on this issue as others did not find much support to it (Holman, \& Graves, 1995; Chen, 2009; Anwar \& Sampath, 1997). Thus, the present paper not only incorporates FDI but also examines the long run relationship amongst exports, FDI and economic growth in Nigeria including possible adjustment processes.

The paper is organized into five sections including this introduction. Section two covers the literature while section three discusses methodological issues and data. Section four presents the empirical results and discussion while section five concludes the paper.

\section{Theoretical Framework and Empirical Evidence}

\subsection{Theoretical Framework}

The argument concerning the role of exports as one of the main deterministic factors of economic growth is not new. It goes back to the classical economic theories by Adam Smith and David Ricardo, who argued that international trade plays an important role in economic growth, and that there are economic gains from specialization. It was also recognized that exports provide the economy with foreign exchange needed for imports that cannot be produced domestically. Thus, the relationship between exports and economic growth is theoretically rooted in the export-led growth (ELG) hypothesis. The hypothesis argues for government restriction of import trade and encouragement of strategies that support manufacturing sector with a view to promoting potential comparative advantage and growth (Elbeydi, 2010). It is based on a notion that international trade could promote specialization in the production of export products and reallocation of resources from relatively inefficient non-export trade sector to the more productive exports trade sector thereby leading to growth (Edwards, 1992; Lucas, 1988; Helpman, \& Krugman,1985; Feder, 1983). The ELG paradigm has received renewed attention following the highly successful East Asian export-led growth strategy during the 1970s and 1980s, and especially when compared with the overall failure of import substitution policies adopted by African and Latin American countries (Abou-Stait, 2005).

Theoretically, export-led growth appears among neoclassical economists after the victorious story of newly industrialized Asian countries. They argue that, for instance, Taiwan, Hong Kong, Singapore and Korea, the Four Asian Tigers, have been successful in achieving high and persistent rates of economic growth since early 1960s; because of their free-market, outward-oriented economies. Thus, the emergence of endogenous growth theories put emphasis on the benefits resulting from a dynamic export trade in a framework that will lead to increasing returns to scale and diffusion of technological and managerial effects from abroad to the other sectors of the economy (Alisana, $\&$ Rodrick, 1999; Feder, 1983). The theoretical arguments are further supported by some empirical studies as seen in the next section. 


\subsection{Some Empirical Evidence}

The empirical studies on the relationship between exports and economic growth are usually classified into two broad categories depending on the type of data used for analysis i.e. the cross-sectional and time series studies. Although, evidences from both categories of studies have yielded a mixed result, there exist significant numbers of other studies that identify exports as an important factor in determining growth (Shirazi, \& Manap, 2004). However, our focus in this paper is on those studies that utilized time-series data.

Erecakar (2011) for instance, analyzed the relationship among growth, foreign direct investment, trade and inflation in Turkey over the period of 1970 and 2008 using co-integration technique to establish their long run relationship. The results of the study indicated that only one co-integrating relation exists among the variables. The results further disclosed that while foreign direct investment, inflation and trade surplus have positive and statistically significant impact on GDP growth, the coverage ratio of exports for import has a negative impact on GDP growth.

Miankhel, et al. (2009) also investigated the impact of foreign direct investment and exports on economic growth of six (6) emerging countries of Chile, India, Mexico, Malaysia, Pakistan and Thailand using a multivariate VAR analysis approach. The results of the study have favoured exports led growth hypothesis in South Asian countries. The study has further provided evidence of Long-run impact of exports on growth of FDI and GDP in Latin-American countries of Mexico and Chile. Finally, the study established the existence of bi-lateral causality between GDP and FDI in Thailand, while no evidence of such relationship in the case of Malaysia.

Ullah, et al. (2009) examined the validity of export-led growth hypothesis in Pakistan for the period 1970-2008. The study employed cointegration and causality framework and the results revealed the existence of unidirectional causality from GDP to exports. Similarly, Pop Silaghi (2009) studied the exports-economic growth causality for 10 Central and Eastern European (CEE) countries over the period 1990 to 2006 using Johansen cointegration and the Vector Error Correction Modeling (VECM) techniques. The results of the study showed the existence of a feedback effect between exports and GDP in three out of 10 countries in the sample.

Jordaan and Eita (2007) studied the causal relationship between exports and economic growth in Namibia for the period 1970-2005. The study concluded that export-led growth strategy has had positive impact on economic growth.

Shirazi and Manap (2004) analyzed both the short-run and long-run relationship among real exports, real import and real output in Pakistan using the cointegration and Toda Yamamoto causality technique for the period 1960-2003. The study found strong evidence of unidirectional causality from exports to economic growth, even though Tang (2006) found no evidence of long-run relationship between exports and economic growth in China.

Thurayia (2004) investigated the relationship between exports and economic growth in Saudi Arabia and Republic of Sudan, using co-integration and error correction framework. The result of the study indicated strong evidence in support of export led growth hypothesis for Saudi Arabia but a week evidence for Sudan.

Anwar and Sampath (2000) examined export-led hypothesis using a large sampling of 97 countries and the result has shown evidence of positive impact of exports on economic growth.

Bahmani-Oskooee and Alse (1993) employed Error-correction modeling (ECM) technique to examine the relationship between exports and economic growth for nine developing countries. The results revealed strong evidence in favour of export-led growth hypothesis for all the countries. Ram (1987) examined the impact of exports growth on economic growth using a sample of 88 LDCs for the period 1960-82 and the study found evidence to validate the export-led growth hypothesis.

Hsiao (1987) study established the causality and exogeneity between exports and economic growth employing the Granger and Sim causality test techniques. The study could not provide evidence to support export-led growth hypothesis. Jung and Marshall (1985) also employed standard Granger causality test to examine export-growth relationship for 37 developing countries. The results showed evidence to support the export-led growth hypothesis in only four countries.

In the case of Nigeria, Chimobi and Uche (2010) studied the relationship between exports, domestic demand and economic growth using the Granger causality technique to determine the direction of causality. The results of the study showed that economic growth Granger caused both exports and domestic demand while exports caused domestic demand. Osinubi and Amaghionyeodiwe (2010) too carried out empirical investigation of foreign private investment and economic growth in Nigeria, using co-integration and error-correction framework over the period covering 1970 to 2005 . The study found that foreign private investment, domestic investment growth and net export growth positively influenced economic growth in Nigeria. Similarly, Ayanwale and Bamire (2004), and Ayashagba and Abachi (2002) found positive effect of FDI on economic growth for Nigeria. 


\section{Methodological Issues and Data}

As we observed in the previous section, many studies have used the cointegration and error correction specification. The present study adopts same as evident from existing literature such as Thuravia (2004), Shirazi and Manap (2004) and Pop Silaghi (2009) concentrating on a multivariate case.

Our key variables for this study are the Real gross domestic product(RGDP) representing the macroeconomy, Foreign direct investment(FDI), Real export (REXP), while the control variables are Degree of openness (DOP), Gross fixed capital formation(GFCF), Inflation rate (INF), Real exchange rate (REXR), Real import (RIMP) and Terms of trade(TOT). We use the normal series of the variables for all our computations without logarithmic transformation. This is due to the nature of the variables considered. For instance taking the log of DOP, EXR, etc may result in negative values, which seems not to make economic sense.

\subsection{The Model}

First, we observe the behaviour of each variable through some diagnostic test and this is followed by examination of the stochastic properties based on Phillips-Peron test. We adopt the Phillips-Perron (PP) test in our case on the ground that it is robust to a wide variety of serial correlation and heteroscedasticity. Phillips and Perron (1988) developed a generalization of the ADF test procedure that allows for mild assumptions regarding the distribution of the error process and thus it modifies the ADF test. The PP test is based on an AR (1) processes

$$
\begin{gathered}
\Delta y_{t}=\beta_{0}+\beta_{1} y_{t-1}+e_{t} \\
\text { and } \Delta y_{t}=\beta_{0}+\beta_{1} t+\beta_{2} y_{t-1}+e_{t}
\end{gathered}
$$

Equation 2 includes a linear trend; the PP test is the $t$ value associated with the estimated coefficients $\beta_{1}$ and $\beta_{2}$ $<0$ and significant for no unit root.

Except for the case of all variables being I (0), we move on to the cointegration test based on the Johansen approach (Johansen \& Juselius, 1990) is carried out in a multivariate frame. Consider using matrix notation for

$$
Z_{t}=\left|Y_{t}, X_{t}, Q_{t}\right|, \quad Z_{t}=A_{1} Z_{t-1}+A_{2} Z_{t-2}+A_{3} Z_{t-3}+\ldots . .+A_{k} Z_{t-k}+\mu_{t}
$$

The vector error- correction model representation is

$$
\begin{gathered}
\Delta Z_{t}=\Gamma_{1} \Delta Z_{t-1}+\Gamma_{2} \Delta Z_{t-2}+\Gamma_{3} \Delta Z_{t-3}+\ldots \ldots+\Gamma_{k-1} \Delta Z_{t-k-1}+\Pi Z_{t-1}+\mu_{t} \\
\left.\Gamma_{i}=\left(1-A_{1}-A_{2}-A_{3}-\ldots . .-A_{k}\right) \quad \text { for } i=1,2,3, \ldots \ldots ., k-1\right) \text { and } \Pi=-\left(1-A_{1}-A_{2}-A_{3}-\ldots \ldots . . A_{k}\right)
\end{gathered}
$$

The $\Pi$ matrix is a $3 \times 3$ since we have 3 variables in $Z_{t}=\left|Y_{t}, X_{t}, Q_{t}\right|$ and contains information about the longrun relationships. We decomposed $\Pi=\theta_{1} \theta_{2}{ }^{\prime}$ where $\theta_{1}$ and $\theta_{2}{ }^{\prime}$ include the speed of adjustment to equilibrium coefficients and long-run matrix of coefficients respectively. Assuming $k=2$ for simplicity, we can write

$$
\left(\begin{array}{l}
\Delta Y_{t} \\
\Delta X_{t} \\
\Delta Q_{t}
\end{array}\right)=\Gamma_{1}\left(\begin{array}{l}
\Delta Y_{t-1} \\
\Delta X_{t-1} \\
\Delta Q_{t-1}
\end{array}\right)+\Pi\left(\begin{array}{l}
\Delta Y_{t-1} \\
\Delta X_{t-1} \\
\Delta Q_{t-1}
\end{array}\right)+e_{t}=\left(\begin{array}{l}
\Delta Y_{t} \\
\Delta X_{t} \\
\Delta Q_{t}
\end{array}\right)=\Gamma_{1}\left(\begin{array}{l}
\Delta Y_{t-1} \\
\Delta X_{t-1} \\
\Delta Q_{t-1}
\end{array}\right)+\left(\begin{array}{l}
a_{11} a_{12} \\
a_{21} a_{22} \\
a_{31} a_{32}
\end{array}\right)\left(\begin{array}{l}
\beta_{11} \beta_{21} \beta_{31} \\
\beta_{12} \beta_{22} \beta_{32}
\end{array}\right)\left(\begin{array}{l}
Y_{t-1} \\
X_{t-1} \\
Q_{t-1}
\end{array}\right)+e_{t}
$$

Now the ECM part of

$$
\Delta Y_{t}=Z_{t-1}=a_{11}\left(\beta_{11} Y_{t-1}+\beta_{21} X_{t-1}+\beta_{31} Q_{t-1}\right)+a_{12}\left(\beta_{12} Y_{t-1}+\beta_{22} X_{t-1}+\beta_{32} Q_{t-1}\right)
$$

which shows two cointegrating vectors with speed of adjustment to equilibrium, $a_{11}$ and $a_{12}$.

The Johansen approach uses two likelihood test statistics, namely the trace $\left(\lambda_{\text {trace }}\right)$ and the maximum eigenvalue

$\left(\lambda_{\max }\right)$. Consider hypothesis $H_{1}: r_{0}<r \leq k$, it can be tested using the statistic $\lambda_{\text {trace }}\left(r_{0}\right)=-T \sum_{j=r_{0}+1}^{k} \log \left(1-\tilde{\lambda}_{j}\right)$

The test is so-called trace test because it verifies whether the smallest $k-r_{0}$ eigenvalues are significantly different from zero. Moreover, hypothesis $\mathrm{H}_{0}: \mathrm{r} \leq \mathrm{r}_{0}$ can be tested against a more restrictive alternative $H_{1}: r=r_{0}+1$ using

$$
\lambda_{\max }\left(r_{0}\right)=-T \sum_{j=r_{0}+1}^{k} \log \left(1-\tilde{\lambda}_{j}\right)
$$


This alternative test is called the maximum eigenvalue test, as it is based on the estimated $H_{1}: r=r_{0}+1$ largest eigenvalue (Verbeek, 2004).

For the specific case, the model linking RGDP, REXP, FDI and other control variables is:

$$
\begin{gathered}
R G D P=f(D O P, F D I, G F C F, R E X P, R E X R, R I M P, T O T, \varepsilon) \\
\left.R G D P=\alpha_{0}+\alpha_{1} D O P+\alpha_{2} F D I+\alpha_{3} G F C F+\alpha_{4} R E X P+\alpha_{5} R E X R+\alpha_{6} R I M P+\alpha_{7} T O T+\alpha_{8} \varepsilon\right)
\end{gathered}
$$

Where $R G D P=$ Real gross domestic product, $D O P=$ Degree of Openness, $F D I=$ Foreign Direct Investment $G F C F=$ Gross fixed capital formation, $R E X P=$ Real exports, $R E X R=$ Real exchange rate, $R I M P=$ Real import, and TOT $=$ terms of trade. $\alpha_{0}, \alpha_{1}, \alpha_{2} \ldots \ldots \ldots \alpha_{6}$ are slope coefficients except for $\alpha_{0}$ and $\varepsilon=$ error term

\subsection{Data Source}

The annual data used for this study were obtained from the Statistical Bulletin and Annual Reports published by the Central Bank of Nigeria (CBN) over the period 1960-2009. However, data for GFCF started from 1981, FDI data from 1962 and INF data from 1961. Those periods for which the data were not available are considered as missing values and tagged "not available (NA)" by the computational tool. Data for DOP were computed using ratio of sum of export and import to the GDP, the export and import data were deflated to get their real terms

\section{Results and Discussion}

The diagnostic test carried out first using time series plots displays the varying nature of the variables used. The plots show that most of the variables appear with trend but the exchange rate variable does not show a clear pattern of trend behaviour. The correlogram computed shows that for all the variables, the autocorrelations and partial autocorrelations at all lags $(k) \neq 0$ and nearly all the $Q$-statistic denoted by $Q=T \sum_{k=1}^{m} \rho_{k}^{2}$ are significant where $T=$ sample size, $m=$ lag length happen and $\rho_{k}=$ autocorrelation coefficient. Hence, we reject $H_{0}=\rho_{1}=\rho_{2}=\rho_{3}=\ldots . .=\rho_{k}=0$

(12) in the present case (correlogram results are too cumbersome to display here but available upon request). Except for other variables, the largest probability value of 0.226 displayed by the inflation series makes it not to be significant at $k=20$.

So far, the P-P test result displayed in appendix using Newey-West automatic based on Bartlett Kernel indicates that the highest number of times a series is differenced before attaining stationarity=number of unit roots=number of integration $=2$ and no series has a unit root, even though most have different order of integration. Only $22.2 \%$ of the variables used are I(0) and this includes INF and TOT, 44.4\% are I(1) involving GFCF, REXR and RGDP and 33.3\% are I(2) with DOP, FDI and REXP, this is evident from the P-P test statistic and their respective probabilities. Our results support the claim that most economic variables are I(1).

The Johansen test for cointegration was carried out and the result shown in appendix. The result indicates that at least 6 cointegrating vectors for trace test and 4 cointegrating vectors for max-eigen test. In other words, we accept the hypothesis $r=0, r=1, r=2, r=3, r=4, r=5$ and $r=0, r=1, r=2, r=3$ cointegrating equations for the trace and max-Eigen tests. The high number of cointegrating vectors supports the claim of stability of the system of equations, the higher the number of cointegrating vectors. Our finding of long-run relationship supports some findings in the literature. For example, it is in line with that of Erecakar(2011) who investigated the long run relationship among growth, FDI, trade and inflation in Turkey but contrary to Tang(2006) who found no evidence of long-run relationship between exports and economic growth in China. Explaining this on a theoretical ground, the existence of a long -run relationship among these variables is not surprising. The key variables RGDP, FDI and REXP and the control variables DOP, GFCF, INF, REXR, RIMP and TOT interact through a chain of transmission mechanism. For instance, a rise in export increases the degree of openness which may result in technological transfer through FDI and increasing the level of Gross fixed capital formation and then stability in the exchange rate and inflation rate. This may necessitate the terms of trade to be favourable and import on the decline. However, the analysis does not clearly show which of the variables is cointegrating with one another and by what magnitude.

The error correction result clearly shows that the error correction term is negative and significant $(0.48)$. This implies that $48 \%$ of the adjustment takes place each period suggesting that deviation from long run RGDP path is corrected by about $48 \%$ over the following year. The RGDP equation showing the error correction term is

$\Delta R G D P=11868.00-891.96 \Delta D O P-0.06 \Delta F D I+0.04 \Delta G F C F+267.98 \Delta I N F-0.38 \Delta R E X P+36315.87 \Delta R E X R+2.51 \Delta R I M P-4757.78 \Delta T O T$ -0.48 ecm $_{t-1}$ 
with the $t$-statistic for $e c m_{t-1}=-3.01$ and is highly significant. The dynamic process of the variables used for the error correction computation was computed by the authors and is available on request.

The summary of the cointegrating regression determining the long run relationship is computed for the RGDP functions as indicated in table III and the full cointegrating regression results are contained in tables IV and V, all provided in the appendix.

From the cointegrating regression result using a fully modified least squares method, only the DOP, FDI, GFCF, REXR and TOT meet the theoretical expectation with FDI being significant. By implication, a 1 unit rise in DOP gives rise to about a rise of 715 units in the RGDP. This explains the relevance of openness of the economy through exposures to various trade interactions. Other variables for which a unit change would cause a very large change on the economy are INF, REXR and TOT. However, 1 unit increase in the RIMP creates about 31.2 units increase in the RGDP. Even though the variables FDI and GFCF have the expected signs, they have small unit increases in the RGDP for 1 unit rise in each of them compared to other variables with large impact. The FDI and GFCF, though, expected to remain as catalysts that can speed up the rate of growth, but this result may be deduced from the parasitic nature of FDI as described by some literature. If really, this holds, then there is possibility of FDI over-taking the domestic investment environment. The positive effects of FDI and GFCF support some findings in Nigeria such as Osinubi and Amaghionyeodiwe (2010) who found that foreign private investment, domestic investment growth and net export growth positively influenced economic growth. Our finding is also in agreement with the work of Ayashagba and Abachi (2002) who obtained a positive effect of FDI on economic growth for Nigeria. It is however, surprising that the REXP and RIMP are of the contrary sign to theoretical expectation, even though both are significant with REXP having a larger coefficient. This may be explained by the periods of macroeconomic fluctuations including the recessionary periods that tend to wipe out the potential gains from what may serve as an injection to the economy and then seemed to make external dependency a major growth driven. However, the inclusion of both the DOP and REXP in the RGDP function calls for concern especially on the stability of the estimated coefficients. We therefore tested for the presence of multicollinearity in the model. We first obtained the correlation matrix of the entire variables with the results being symmetrical. The diagonal elements are equal to 1 since they are correlations of same variables. We also noted that the correlation of DOP and REXP is as high as 0.956 (about the highest apart from the diagonal elements) showing the possibility of the negative effects of multicollinearity. Theoretically, correlations among variables may not be enough to justify the presence of multicollinearity. We therefore compared the full model OLS to the one with omitted variable suspected to cause multicollinearity problem. In the full static regression model, apart from the contrary signs of the coefficients of some of the explanatory variables particularly the REXP, the standard error reads 51931.06 with $R^{2}=0.88$. Since our key variable is REXP, we dropped DOP from the new cointegrating regression and the summary of the result is contained in table III while the detailed one is presented in table V, both in the appendix.

Dropping the DOP increases the extent of the variables not being significant. For example, this has led to the non-significance of REXR which was initially significant when the DOP was included. Though in the two cases, all the explanatory variables have high explanatory power and are within close range with $\mathrm{R}^{2}=0.865$ for the model with DOP and $R^{2}=0.863$ for the model excluding DOP. Meanwhile, the coefficients of the variables GFCF, INF and REXP also reduced. It is quite noticeable that the standard error of regression is higher than before, and this implies a larger variance. It seems, therefore, that removal of DOP from the model significantly changes the model structure; hence removal of DOP might be detrimental. The only outstanding feature noticeable is just that autocorrelation seems to have been corrected partly due to the increased Durbin-Watson Statistic in the model excluding DOP. We equally have same number of cointegrating vectors for both trace and max-Eigen tests as before. The error correction representation in this case is:

$\Delta R G D P=12314.77-0.05 \Delta F D I+0.04 \Delta G F C F+278.45 \Delta I N F-0.12 \Delta R E X P+35182.21 \Delta R E X R+2.16 \Delta R I M P-7880.58 \Delta T O T-0.48 e c m_{t-1}$

with error correction term coefficient being negative and is highly significant $(t-$ ratio $=-3.09)$. Even with DOP omitted, same percentage deviation from long run equilibrium position is corrected for.

\section{Concluding Remarks}

The study has examined the relationship among the exports, FDI and economic growth in Nigeria over the period 1960-2009. The results of the study have found among other things that FDI, capital formation, degree of openness, import and terms of trade played a significant role in the economy along side with other variables particularly as demonstrated by the long run relationship. As a matter of fact, this result is slightly different compared to the former when the DOP suspected to cause multicollinearity problem is dropped. The paper, therefore, concludes by shedding 
more light on the relevance of the degree of openness and can facilitate more FDI inflows capable of accelerating the growth process. Finally, the paper recommends immediate focus on more reforms/policies that will create enabling environment for FDI inflows and export growth thereby reducing the growth and development barriers in Nigeria.

\section{References}

Abou-Stait, F. (2005). Are exports the engine of economic growth? An application of cointegration and causality analysis for Egypt, 1977-2003 Economic Research Working Paper Series. Tunis: African Development Bank.

Adelegan, J. O. (2000). Foreign direct investment and economic growth in Nigeria: A seemingly unrelated model. African Review of Money, Finance and Banking, supplementary issue of savings and Development, 2000 pp 5-25. Milan, Italy.

Alisana, A., \& Rodrik, D. (1999). Distributive politics and economic growth. Quarterly Journal of Economics, 109, 443-465.

Al-Yousif, Y. K. (1999). On the Role of Exports in the Economic Growth of Malaysia: A Multivariate Analysis. International Economic Journal, 13(3), Autumn.

Anwar, M. S., \& Sampath. (1997). Exports and Economic Growth, Paper Presented at Western Agricultural Economic Association 1997 Annual Meeting, July 13 - 16, Reno/Sparks, Nevada.

(2000). Exports and Economic Growth. Indian Economic Journal, 47(3), 79 - 88.

Ayanwale, A. B., \& Bamire, S. (2004). Direct Foreign Investment and Firm-Level Productivity in the Nigeria Agro/agro-allied Sector. Journal of Social Sciences, 9(1), 29-36.

Ayashagba, G. I., \& Abachi, P. I. (2002). The Impact of Foreign Direct Investment (FDI) On Economic Growth of the Less Developed Countries (LDCs): A Case of Nigeria (1980-1997). Journal of Economic and Social Research, 1, $108-125$.

Bahmani-Oskooee, M., \& Alse, J. (1993). Export Growth and Economic Growth: An Application of Co-integration and Error-Correction Modelling. Journal of Developing Areas, 27(4), 535 - 542.

Chen, H. (2009). A Literature Review on the Relationship between Foreign Trade and Economic Growth. International Journal of Economics and Finance, 1(1). Retrieved from http://www.ccsenet.org/journal.html

Chimobi, O. P., \& Uche, U. C. (2010). Exports, Domestic Demand and Economic Growth in Nigeria: Granger Causality Analysis. European Journal of Social Sciences, 13(2). Retrieved from http://www.eurojournals.com/ejss_13_2_06.pdf

Edwards, S. (1992). Trade Orientation, Distortions and Growth in Developing Countries. Journal of Development Economics, 39, 31-57. http://dx.doi.org/10.1016/0304-3878(92)90056-F

Elbeydi, K. R. M. (2010). The Relationship between Export and Economic Growth in Libya Arab Jamahiriya. Theoretical and Applied Economics, XVII, 1 (542), 69 - 76.

Erecakar, M. E. (2011). Growth, Foreign Direct Investment, Trade and Inflation: An Empirical Application on Turkey. Middle Eastern Finance and Economics, 9,137-147. Retrieved from http://www.eurojournals.com/MEFE.htm

Feder. (1983). On Exports and Economic Growth. Journal of Development Economics, 12(1), 59-73. http://dx.doi.org/10.1016/0304-3878(83)90031-7

Helpman, E., \& Krugman, P. (1985). Market Structure and Foreign Trade, MIT Press, Cambrigde.

Holman, J. A., \& Graves, P. E. (1995). Korean Exports Economic Growth: An Econometric Reassessment. Journal of Economic Development, 20(2).

Hsiao, M. W. (1987). Tests of Causality and Exogeneity Between Exports and Economic Growth: The Case of Asian NICs. Journal of Economic Development, 12(2), 143-159.

Johansen, S., \& Juselius, K. (1990). Maximum Likelihood Estimation and Inference Cointegration with Applications to the Demand for Money. Oxford Bulletin of Economics and Statistics.

Jordaan, A. C., \& Eita, J. H. (2007). Exports and Economic Growth in Namibia: A Granger Causality Analysis. South African Journal of Economics, 75(3).

Testing the Export-Led Growth Hypothesis for Botswana. A Causality Analysis, BOJE: Botswana Journal of Economics. 
Jung, W., \& Marshall, P. (1985). Exports, Growth and Causality in Developing Countries. Journal of Development Economics, 18. http://dx.doi.org/10.1016/0304-3878(85)90002-1

Lucas, R. E. (1988). On the Mechanics of the Economic Development. Journal of Monetary Economics. 22, 3 - 42. http://dx.doi.org/10.1016/0304-3932(88)90168-7

Maneschiold, P. (2008). A Note on the Export-Led Growth Hypothesis: A Time Series Approach. Cuadernos De Economia, 45, 293-302.

Miankhel, A. K., Thangavelu, S. M., \& Kalirajan, K. (2009). Foreign Direct Investment, Exports, and Economic Growth in South Asia and Selected Emerging Countries: A Multivariate VAR Analysis. Center for Contemporary Asian Studies Doshisha University, CCAS Working Paper, No. 23.

Musonda, I. (2007). Is Economic Growth Led by Exports in Zambia? Ministry of Finance and National Planning Planning and Economic Management Lusaka, Zambia.

Osinubi, T. S., \& Amaghionyeodiwe, L. A. (2010). Foreign Private Investment and Economic Growth in Nigeria. Review of Economic and Business Studies, 3(1), 105 - 127. Retrieved from http://www.rebs.ro

Phillips, P., \& Perron, P. (1988). Testing for a Unit Root in Time Series Regression. Biometrika, 75, 335-346. http://dx.doi.org/10.1093/biomet/75.2.335

Pop Silaghi, M. L. (2009). Exports-Economic Growth Causality: Evidence from CEE Countries. Romanian Journal of Economic Forecasting, 2, 105-116.

Ram, R. (1987). Exports and Economic Growth in Developing Countries: Evidence from Time Series and Cross-Sectional Data. Economic Development and Cultural Change, 36, 51 - 72. http://dx.doi.org/10.1086/451636

Shirazi, N. S., \& Manap, T. A. A. (2004). Export-Led Growth Hypothesis: Further Econometric Evidence from Pakistan. The Pakistan Development Review, 43(4), 563-581.

Tang, T. C. (2006). New Evidence on Export Expansion, Economic Growth and Causality in China. Applied Economics Letters, 20.

Thurayia, S. (2004). The Relationship between Exports and Economic Growth Experience of Saudi Arabia and Republic of Sudan. Economic Studies: Scientific Series of Saudi Economic Association, 6(A11).

Ullah, S., Zaman, B. U., Farooq, M., \& Javid, A. (2009). Cointegration and Causality between Exports and Economic Growth in Pakistan. European Journal of Social Sciences, 10(2), 264-272. Retrieved from http://www.eurojournals.com/ejss

Verbeek, M. (2004). A Guide to Modern Econometrics, $\left(2^{\text {nd }}\right.$ Ed). John Wiley, \& Sons, Ltd: England.

Table 1. Phillips-Perron Unit Root Test Result Summary

\begin{tabular}{|c|c|c|c|c|}
\hline Variable & P-P test statistic & $5 \%$ level critical value & Order of integration & Probability \\
\hline DOP & -13.01 & -3.51 & $\mathrm{I}(2)$ & 0.00 \\
\hline FDI & -12.05 & -3.51 & $\mathrm{I}(2)$ & 0.00 \\
\hline GFCF & -4.06 & -3.59 & $\mathrm{I}(1)$ & 0.02 \\
\hline INF & -4.05 & -3.51 & $\mathrm{I}(0)$ & 0.01 \\
\hline REXP & -20.32 & -3.51 & $\mathrm{I}(2)$ & 0.00 \\
\hline REXR & -5.755 & -3.51 & $\mathrm{I}(1)$ & 0.00 \\
\hline RGDP & -6.60 & -3.51 & $\mathrm{I}(1)$ & 0.00 \\
\hline RIMP & -10.38 & -3.51 & $\mathrm{I}(1)$ & 0.00 \\
\hline TOT & -4.51 & -3.50 & $\mathrm{I}(0)$ & 0.00 \\
\hline
\end{tabular}

Source: Authors' computation. using Eviews. 
Table 2. Cointegration Test Results

Date: 10/22/11 Time: 18:29

Sample (adjusted): 19832009

Included observations: 27 after adjustments

Trend assumption: Linear deterministic trend

Series: DOP GFC INF REXP REXR RGDP RIMP TOT

Lags interval (in first differences): 1 to 1

Unrestricted Cointegration Rank Test (Trace)

\begin{tabular}{ccccc}
\hline $\begin{array}{c}\text { Hypothesized } \\
\text { No. of CE(s) }\end{array}$ & Eigenvalue & $\begin{array}{c}\text { Trace } \\
\text { Statistic }\end{array}$ & $\begin{array}{c}0.05 \\
\text { Critical Value }\end{array}$ & Prob.** \\
\hline None * & 0.954609 & 282.9651 & 159.5297 & 0.0000 \\
At most $*^{*}$ & 0.887609 & 199.4695 & 125.6154 & 0.0000 \\
At most 2 & 0.822051 & 140.4536 & 95.75366 & 0.0000 \\
At most 3* & 0.757954 & 93.84465 & 69.81889 & 0.0002 \\
At most 4 & 0.564649 & 55.54173 & 47.85613 & 0.0080 \\
At most 5* & 0.549307 & 33.08849 & 29.79707 & 0.0202 \\
At most 6 & 0.335928 & 11.57031 & 15.49471 & 0.1787 \\
At most 7 & 0.018983 & 0.517469 & 3.841466 & 0.4719 \\
\hline
\end{tabular}

Trace test indicates 6 cointegrating eqn(s) at the 0.05 level

$*$ denotes rejection of the hypothesis at the 0.05 level

**MacKinnon-Haug-Michelis (1999) p-values.

Unrestricted Cointegration Rank Test (Maximum Eigenvalue)

\begin{tabular}{ccccc}
\hline $\begin{array}{c}\text { Hypothesized } \\
\text { No. of CE(s) }\end{array}$ & Eigenvalue & $\begin{array}{c}\text { Max-Eigen } \\
\text { Statistic }\end{array}$ & $\begin{array}{c}0.05 \\
\text { Critical Value }\end{array}$ & Prob.** \\
\hline None $*$ & 0.954609 & 83.49569 & 52.36261 & 0.0000 \\
At most $1 *$ & 0.887609 & 59.01588 & 46.23142 & 0.0014 \\
At most $2 *$ & 0.822051 & 46.60893 & 40.07757 & 0.0080 \\
At most $3 *$ & 0.757954 & 38.30291 & 33.87687 & 0.0139 \\
At most 4 & 0.564649 & 22.45325 & 27.58434 & 0.1980 \\
At most $5 *$ & 0.549307 & 21.51818 & 21.13162 & 0.0441 \\
At most 6 & 0.335928 & 11.05284 & 14.26460 & 0.1516 \\
At most 7 & 0.018983 & 0.517469 & 3.841466 & 0.4719 \\
\hline
\end{tabular}

Max-eigenvalue test indicates 4 cointegrating eqn(s) at the 0.05 level

* denotes rejection of the hypothesis at the 0.05 level

**MacKinnon-Haug-Michelis (1999) p-values

Source: Authors' computation using Eviews.

Table 3. Summary of Cointegrating Regression using Fully Modified Least squares (FMOLS) Method

a. Model with DOP included

b. Model with DOP excluded

\begin{tabular}{|c|c|c|c|c|c|c|}
\hline EXP.VAR & COEFF & T-STAT & DECISION & COEFF & T-STAT & DECISION \\
\hline DOP & 715.73 & 0.238 & not sig & ------- & ------ & ------- \\
\hline FDI & 0.597 & 3.77 & Sig & 0.663 & 3.879 & Sig \\
\hline GFCF & 0.032 & 1.5854 & not sig & 0.022 & 0.9299 & not sig \\
\hline INF & 1472.072 & 4.1576 & Sig & 1435.94 & 3.5135 & Sig \\
\hline REXP & -18.081 & 4.4144 & Sig & -18.678 & -4.8463 & Sig \\
\hline REXR & 25519.29 & 1.7872 & sig & 22959.65 & 1.36995 & not sig \\
\hline RIMP & 31.201 & 5.8928 & Sign & 32.926 & 5.689 & Sig \\
\hline TOT & 258823.1 & 5.6396 & Sign & 266902.8 & 5.354 & Sig \\
\hline C & -319798 & -4.331 & & -337202 & -4.0191 & \\
\hline
\end{tabular}

$\begin{array}{lll}\mathrm{R}^{2}, \mathrm{DW} & 0.87,1.48 & 0.86,1.55\end{array}$

Key: sig. means statistically significant and not sig. means not statistically significant

Source: Authors' computation using Eviews 
Table 4. Cointegrating Regression with DOP

\begin{tabular}{|c|c|c|c|c|}
\hline \multicolumn{5}{|c|}{ Dependent Variable: RGDP } \\
\hline \multicolumn{5}{|c|}{ Method: Fully Modified Least Squares (FMOLS) } \\
\hline \multicolumn{5}{|c|}{ Date: $03 / 02 / 12 \quad$ Time: $20: 37$} \\
\hline \multicolumn{5}{|c|}{ Included observations: 28 after adjustments } \\
\hline \multicolumn{5}{|c|}{ Cointegrating equation deterministics: $\mathrm{C}$} \\
\hline \multicolumn{5}{|c|}{ Long-run covariance estimate (Bartlett kernel, Newey-West fixed bandwidth } \\
\hline \multicolumn{5}{|l|}{$=4.0000)$} \\
\hline Variable & Coefficient & Std. Error & t-Statistic & Prob. \\
\hline DOP & 715.7300 & 3001.874 & 0.238428 & 0.8141 \\
\hline FDI & 0.596900 & 0.158317 & 3.770281 & 0.0013 \\
\hline GFCF & 0.031991 & 0.020179 & 1.585359 & 0.1294 \\
\hline INF & 1472.072 & 354.0629 & 4.157657 & 0.0005 \\
\hline REXP & -18.08109 & 4.095904 & -4.414433 & 0.0003 \\
\hline REXR & 25519.29 & 14279.05 & 1.787184 & 0.0899 \\
\hline RIMP & 31.20121 & 5.294811 & 5.892790 & 0.0000 \\
\hline TOT & 258823.1 & 45893.78 & 5.639612 & 0.0000 \\
\hline $\mathrm{C}$ & -319797.5 & 73835.66 & -4.331207 & 0.0004 \\
\hline R-squared & 0.865250 & Mean dependent var & & 248001.0 \\
\hline Adjusted R-squared & 0.808513 & S.D. dependent var & & 123020.6 \\
\hline S.E. of regression & 53832.81 & Sum squared resid & & $5.51 \mathrm{E}+10$ \\
\hline Durbin-Watson stat & 1.479555 & Long-run variance & & $1.09 \mathrm{E}+0 \mathrm{~s}$ \\
\hline
\end{tabular}

Source: Authors' computation using Eviews.

Table 5. Cointegrating Regression without DOP

Dependent Variable: RGDP

Method: Fully Modified Least Squares (FMOLS)

Date: 03/02/12 Time: 20:41

Included observations: 28 after adjustments

Cointegrating equation deterministics: $\mathrm{C}$

Long-run covariance estimate (Bartlett kernel, Newey-West fixed bandwidth

\begin{tabular}{|c|c|c|c|c|}
\hline Variable & Coefficient & Std. Error & t-Statistic & Prob. \\
\hline FDI & 0.662622 & 0.170815 & 3.879186 & 0.0009 \\
\hline GFCF & 0.021588 & 0.023215 & 0.929917 & 0.3635 \\
\hline INF & 1435.940 & 408.6869 & 3.513546 & 0.0022 \\
\hline REXP & -18.67843 & 3.854132 & -4.846339 & 0.0001 \\
\hline REXR & 22959.65 & 16759.43 & 1.369954 & 0.1859 \\
\hline RIMP & 32.92594 & 5.787206 & 5.689437 & 0.0000 \\
\hline TOT & 266902.8 & 49847.52 & 5.354386 & 0.0000 \\
\hline $\mathrm{C}$ & -337202.0 & 83899.32 & -4.019127 & 0.0007 \\
\hline R-squared & 0.862683 & Mean dependent var & & 248001.0 \\
\hline Adjusted R-squared & 0.814623 & S.D. dependent var & & 123020.6 \\
\hline S.E. of regression & 52967.10 & Sum squared resid & & $5.61 \mathrm{E}+10$ \\
\hline Durbin-Watson stat & 1.552728 & Long-run variance & & $1.51 \mathrm{E}+09$ \\
\hline
\end{tabular}

Source: Authors' computation using Eviews. 


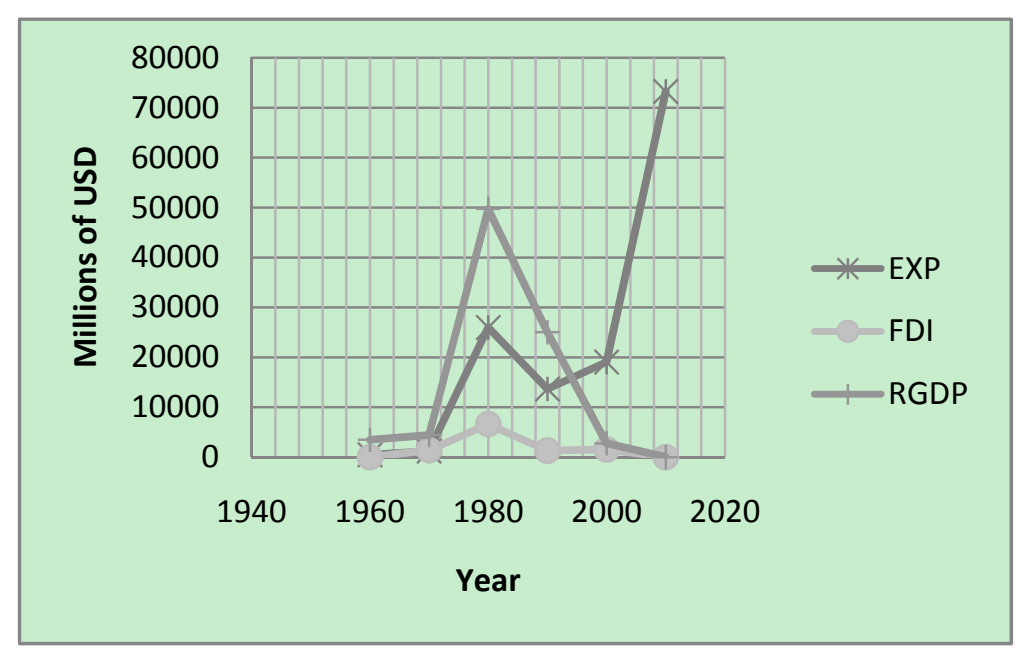

Figure 1. The Trends of Exports, Foreign Direct Investment and Real Gross Domestic Product in Nigeria (1960-2009) 